\title{
Phytochemical Analysis and Evaluation of Bioactivities of Cola acuminata Extracts
}

\author{
Jeff Bekomo Iteku ${ }^{1,2}$, Gédéon Ngiala Bongo ${ }^{1,}{ }^{*}$, Jennifer Ngoie Mbiya ${ }^{1}$, José Mulwahali Wambale ${ }^{4}$, Paulin \\ Kapepula Mutwale ${ }^{4}$, Clément Liyongo Inkoto ${ }^{5}$, Koto-te-Nyiwa Ngbolua ${ }^{2,3}$
}

How to cite this paper: Iteku, J. B., Bongo, G. N., Mbiya, J. N., Wambale, J. M., Mutwale, P. K., Inkoto, C. L., \& Ngbolua, K. N. (2021). Phytochemical Analysis and Evaluation of Bioactivities of Cola acuminata Extracts. Journal of Biomedical and Life Sciences, 1(1), 51-65. Retrieved from https://www.scipublications.com/journal/index.php/jbls/article/view/166

Received: October 27, 2021 Accepted: December 17, 2021 Published: December 18, 2021

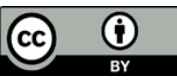

Copyright: (c) 2021 by the authors. Submitted for possible open access publication under the terms and conditions of the Creative Commons Attribution (CC BY) license (http://creativecommons.org/licenses /by/4.0/).

\footnotetext{
${ }^{1}$ Higher Pedagogical Institute of Yakoma, Nord-Ubangi city, Democratic Republic of the Congo

${ }^{2}$ Department of Biology, Faculty of Science, University of Kinshasa, Kinshasa city, Democratic Republic of the Congo

${ }^{3}$ Department of Environmental Sciences, University of Gbadolite, Nord-Ubangi city, Democratic Republic of the Congo

${ }^{4}$ Faculty of Pharmaceutical Sciences, University of Kinshasa, Kinshasa city, Democratic Republic of the Congo

${ }^{5}$ Department of Nutrition, School of Public Health, Faculty of Medicine, University of Kinshasa, Kinshasa city, Democratic Republic of the Congo

*Correspondence: gedeonbongo@gmail.com, gedeon.bongo@unikin.ac.cd
}

Abstract: Background: From centuries of evolution, knowledge and technological progress for mankind to one day rediscover nature. Currently, the control of bacterial infections is becoming complex due to the concern of antibiotic resistance, which has been a significant global health problem. The aim was to determine and compare phytochemical constituents and in the in vitro evaluation of antimicrobial and antioxidant activities of aqueous, methanol, acetate, dichloromethane extracts from Cola acuminata nuts grown in the Nord Ubangi Province, DRC. Methods: The nuts of Cola acuminata were harvested in April 2016 at Yakoma city, Nord-Ubangi, DRC. The microscopic features of this species were performed in order to identify specific histological structures. Three bacterial strains notably Staphylococcus aureus ATCC 25923, Escherichia coli ATCC 8739 and Pseudomonas aeroginosa ATCC 9027 were used for the assessment of the antibacterial activity. The qualitative and quantitative phytochemical screening were used for compound identification using different fractions and fractions which presented a good extraction yield was used for further analysis. The antioxidant activity was evaluated using ABTS and DPPH scavenging tests while the antibacterial activity was performed using the diffusion method. Findings: The micrography of C. acuminata revealed the presence of following histological elements of which: fibers, spiral vessels, trichomes, ovoid starch grains, sclerenchyma and the fragments of endosperm. Only the methanol and aqueous extracts presented a good extraction yield. The phytochemistry shows the presence of flavonoids, anthocyanins, terpenes, iridoids and tannins. All fractions showed IC 50 values lower than 10 $\mu \mathrm{g} / \mathrm{mL}$ in the ABTS test and lower than $100 \mu \mathrm{g} / \mathrm{mL}$ in the DPPH test. The antibacterial activity of this plant was low against the three strains used. Conclusion: Seeing the potency of $C$. acuminata and different biological activities displayed, further analysis are required in order to identify and purify the active ingredients, to study the toxicity of cell lines in vitro, to perform the in vivo experiments and to test for other activities such as the anti-hypoglycemic and anti-inflammatory.

Keywords: Cola acuminata, Phytochemistry, Biological activities, Phytotherapy

\section{Introduction}

From centuries of evolution, knowledge and technological progress for mankind to one day rediscover nature [1]. This rediscover is called phytotherapy and, thanks to it, we 
have found our roots and natural health [1]. Today, the effectiveness of herbal medicine is proven and its undeniable benefits for our health have allowed natural medicine to become part of our daily habits. Even the most developed countries are not left out [2-3]. According to Kouadio et al. [4], medicinal plants are part of the history of all continents: in China and India, over the centuries, knowledge about plants has been organized, documented and transmitted from generation to generation.

Today, the use of herbal treatment is gaining renewed interest in Western countries, particularly to treat the imbalances caused by modern life, whether it is stress or weight problems. The use of traditional medicine is becoming in a daily practice, in terms of prevention. It is no longer reserved for the treatment of diseases [5,6]. In Africa, millions of people use traditional medicine primarily and sometimes exclusively for their primary health care, because it remains the most affordable and seems effective. Others, on the other hand, prefer Western medicine because they combine traditional medicine with superstition [7].

Medicinal plants are effective natural sources for the treatment of various infectious diseases in humans. Scientists are focusing on the discovery of natural compounds from medicinal plants, with the aim of introducing new drugs that will be more effective than those available on the market $[8,9]$. Recent research has focused on the nature of the plant product as an alternative to existing medicines to cure diseases in developing countries $[10,11]$. They have formed the basis of sophisticated traditional medicine and an excellent leader in the development of new drugs. Plants used in traditional medicine contain a wide range of substances that can be used to treat chronic and infectious diseases [10].

Nature has been a source of medicinal agents for thousands of years. Although progress has been made in pharmacology and synthetic organic chemistry, this dependence on natural products, particularly plants, remains largely unchanged [12-14]. These chemical constituents have great potential for medicinal purposes and are exploited by both traditional healers and pharmaceutical companies [15]. Natural substances and plants in particular represent a huge source of chemo-diversity, often with very original structures whose total and profitable synthesis (structural complexity, stereo-specificity...) is often difficult to achieve $[14,16]$. In recent years, we have seen a renewed consumer interest in natural products. This is why manufacturers are increasingly developing processes using extracts and active ingredients of plant origin [12, 17].

Among these potentially interesting new compounds, antioxidants, such as flavonoids, have been particularly studied because of their use in pharmaceuticals, cosmetics and food for their health benefits $[18,19]$. Nowadays, more than 3000 flavonoids are identified and are found particularly in floral pigments or leaves. Flavonoids are mainly known for their antioxidant action, modulating the activity of certain enzymes, vasculoprotective, anti-inflammatory and anti-diabetic $[20,21]$. The increased interest of naturally occurring antioxidants to increase food preservation is explained by the fact that some synthetic antioxidants present risks of carcinogenicity [22].

The Democratic Republic of Congo (DRC), a country known for its natural resources, has a particularly rich and varied flora. Nevertheless, it should be noted that, on the one hand, the number of plant species is decreasing and, on the other hand, the knowledge of traditional doctors is also gradually disappearing. This creates an urgent need to recognize and protect these species and the knowledge associated with them. Research on bioactive molecules of natural origin is one of the priority areas of the pharmaceutical industry, but also doctors and chemists are seeking to better understand the heritage of spontaneous species used in traditional medicine [23].

For this study, Cola acuminata was chosen, which is a very rich source of tannins and flavonoids found in seeds. It is widely used in Africa as a chewable seed for its many therapeutic properties. This species is used by traditional practitioners against diarrhea, 
cough, and dysentery as well as for its astringent analgesic properties [24]. It is in this context that the study was specifically designed to determine and compare phytochemical constituents and in the in vitro evaluation of antimicrobial and antioxidant activities of aqueous, methanol, acetate, dichloromethane extracts from $C$. acuminata nuts grown in the Nord Ubangi Province, DRC. Thus, its effects on the various pathologies have led us to value this plant species, C. acuminata, and to demonstrate the biological activities of its active ingredients. The purpose of this study was to assess the phytochemistry and bioactivities of C. acuminata.

\section{Material and methods}

\subsection{Plant Material}

In this study, the nuts of Cola accumita (P. Beauv. Schott and Endl., 1932) were used. The nuts of the plant were freshly harvested in April 2016 in the territory of Yakoma (Nord Ubangi Province, DRC). The plant was identified at the Institut National des Recherches Agronomiques located at the Faculty of Sciences, Department of Biology, University of Kinshasa. These nuts were dried in the laboratory temperature for three days, which were dried later in order to obtain the fine powder.

\subsection{Bacterial strains}

The bacterial strains used were provided by Microbiology Laboratory of the Faculty of Pharmaceutical Sciences, University of Kinshasa. These include Pseudomonas aeroginosa ATCC9027, Escherichia coli ATCC 8739 and Staphylococcus aureus ATCC 25923.

\subsection{Methods}

\subsubsection{Extract preparation}

Thirty grams of powdered vegetable matter placed in a settling funnel mixed with $300 \mathrm{~mL}$ solvents by increasing polarity (n-hexane, dichloromethane, ethyl acetate, methanol) then macerate for three times 48 hours then collect the filtrate and place in the oven for 3 days at $37^{\circ} \mathrm{C}$.

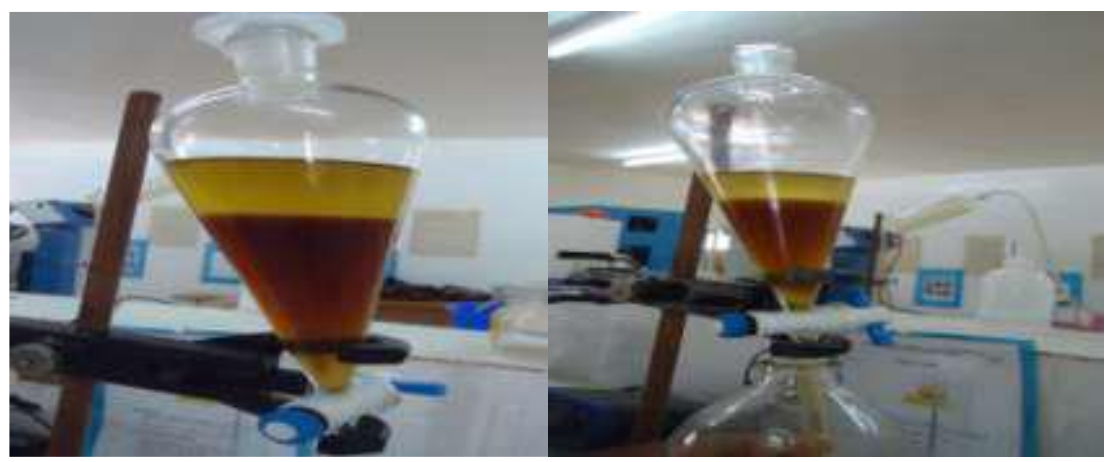

Figure 1. Fractioning of crude extract

\subsubsection{Powder micrography}

This experiment was performed according to Bongo et al. [25]. Microscopic features or powder micrography is one of the most fundamental methods of controlling plant drug quality. It is very important to carry out well the preparation of the plate to be observed under the microscope in order to distinguish different elements constituting the powder. Two-three drops of selected reagent were placed on a slide and a small amount of powder is added. This slide is covered with a cover-slide in order to homogenize the preparation followed by the microscopic feature examination. Observations were made with a Hund WETZLAR microscope, and pictures were taken with Digital Camera CANON IXUS 165. 


\subsubsection{Phytochemical screening using TLC}

Phytochemical screening is a set of techniques used to determine the different chemical groups contained in a plant organ. It is based on physicochemical reactions that make it possible to identify the presence of chemical substances Bongo et al. [25], Uwabunkeonye et al. [26] and Loukmane [27].

\subsubsection{Search for Flavonoids and phenolic acids}

One gram of pulverized drug was extracted with $5 \mathrm{~mL}$ of methanol by stirring for 10 minutes. Afterwards, $10 \mathrm{~mL}$ of filtrate used for Thin Layer Chromatography (TLC) analysis for the determination of different compounds. Silica gel F254 was used as a stationary phase, and ethyl acetate - formic acid - glacial acetic acid - water (100:11:11:26) as mobile phase 1, dichloromethane - formic acid - acetone (80:10:20) as mobile phase 2 and ethyl acetate - methanol - water (100:13.5:10) as mobile phase 3. As controls, Rutin, hyperoside, isoquercitrin and chlorogenic acid were used. Once developed, the chromatogram was observed under UV at 254 and $366 \mathrm{~nm}$ and was then sprayed with the DPBAE/PEG reagent and observed under UV at $366 \mathrm{~nm}$. The presence of flavonoids was marked by the presence of fluorescent spots of various colors (yellow-orange-green) varying according to the structure of highlighted compounds and phenolic acids were observed as blue fluorescent spots.

\subsubsection{Irridoid research}

As for flavonoids, Silicagel F254 remained the stationary phase and ethyl acetatemethanol-water (100: 13.5: 10) was used as mobile phase. The revelation was carried out with sulfuric acid $5 \%$ in ethanol by heating for 10 minutes at $100{ }^{\circ} \mathrm{C}$. True irridoids gave colorations, while other terpenes were colored in black.

\subsubsection{Anthocyanin Research}

For anthocyanins test, stationary phase remained same as described above and ethyl acetate-formic acid - water (100: 10: 40) was considered as the mobile phase. The revelation was performed with phosphoric vanillin on the plate by heating for 10 minutes at $100{ }^{\circ} \mathrm{C}$. The pink coloration shows the presence of anthocyanins.

\subsubsection{Anthraquinones (anthracene heteroglycosides)}

The ethyl acetate-methanol-water (100: 13.5: 10) was used as the mobile phase. Revelation was performed under UV between 254 and $366 \mathrm{~nm}$ and the spraying was performed with ethanolic $\mathrm{KOH}(10 \%)$. The anthraquinones were red colored reflecting red fluorescence at $366 \mathrm{~nm}$, while anthrones were colored in yellow.

\subsubsection{Terpenes}

One gram of pulverized drug was extracted with $10 \mathrm{~mL}$ of dichloromethane by stirring for 15 minutes. The filtrate was evaporated to dryness and the residue was dissolved in $0.5 \mathrm{~mL}$ of toluene. Silicagel F254 was used as stationary phase and ethyl toluene-acetate (93:7) was used as mobile phase. Thymol, menthol, oleanic acid and $1 \mathrm{mg} / \mathrm{mL}$ (methanol) were used as standards. The revelation was performed with sulfuric vanillin by heating for 10 minutes at $100{ }^{\circ} \mathrm{C}$. Terpenes gave various colors using this reagent.

\subsubsection{Coumarins}

The mobile phase used was toluene-ether (1:1, saturated with $10 \%$ acetic acid). This mobile phase was prepared from the mixture of $10 \mathrm{~mL}$ of toluene, $10 \mathrm{~mL}$ of ether and 10 $\mathrm{mL}$ of $10 \%$ acetic acid in a separatory funnel, where lower phase was removed and the upper phase was used as mobile phase. The revelation was performed under UV between 254 and $366 \mathrm{~nm}$ and the spraying was done with ethanolic $\mathrm{KOH}(10 \%)$. The blue color was characteristic of coumarins. 


\subsubsection{Alkaloids}

In an acidic medium, $0.3 \mathrm{~g}$ of drug powder was introduced into an Erlenmeyer flask and $3 \mathrm{~mL}$ of $5 \%$ diluted hydrochloric acid were added. The mixture was sealed and stirred for 30 minutes and the filtrate was collected. In a test tube, five drops of Mayer's reagent was added to one $\mathrm{mL}$ of the filtrate. The presence of alkaloids was observed by the appearance of a white precipitate. In case, where this general test was positive, a thin layer chromatography (TLC) was required. One g of the drug powder was macerated into one $\mathrm{mL}$ of $10 \%$ ammonia in an Erlenmeyer flask; $5 \mathrm{~mL}$ of ethyl acetate (or methanol to extract the quaternaries) was added and stirred for 30 minutes. Further, $20 \mu \mathrm{L}$ and $50 \mu \mathrm{L}$ of filtrate were used for TLC analysis. Dichloromethane-methanol ammonia 25\% (8:2:0.5) served as a mobile phase and $5 \mathrm{mg} / \mathrm{mL}$ caffeine was used as control. The chromatogram was observed under UV between 254 and $366 \mathrm{~nm}$ and was then sprayed using. Draggendorff reagent and observed under visible light. The presence of alkaloids was marked by the presence of spots ranging from yellow-orange to yellow-brown.

\subsubsection{Determination of secondary metabolites}

\subsubsection{Determination of total polyphenols}

Total polyphenol content of extracts was determined using Folin-Ciocalteu method [28]. Ten $\mathrm{mg} / \mathrm{mL}$ of each extract was diluted in methanol $80 \%$ in order to obtain a $1 \mathrm{mg} / \mathrm{mL}$ solution for each extract. Afterwards, for each extract, a reaction mixture composed of 0.5 $\mathrm{mL}$ of extract $5.0 \mathrm{~mL}$ of distilled water and $0.5 \mathrm{~mL}$ of Folin-Ciocalteu reagent was prepared. Three minutes later, $1.0 \mathrm{~mL}$ of saturated $20 \% \mathrm{Na}_{2} \mathrm{CO}_{3}$ solution was added to the mixture. Different mixtures prepared were stirred and incubated at laboratory temperature under shade for one hour. The absorbance was read at $725 \mathrm{~nm}$ and the analysis was performed in triplicate. The amount of total polyphenols was expressed in mg equivalents of gallic acid (GAE) / $g$ of dry extract using the following equation from the calibration line:

$$
\mathrm{y}=1.7097 \ln (\mathrm{x})+5.2062 \text { and } \mathrm{R}^{2}=0.965
$$

where $\mathrm{x}$ is the absorbance and $\mathrm{y}$ is the equivalent of gallic acid $(\mathrm{mg} / \mathrm{g})$.

\subsubsection{Determination of total flavonoids}

The reaction mixture contained one $\mathrm{mL}$ of methanolic solution $(80 \%)$ of each of extracts having a concentration of ten $\mathrm{mg} / \mathrm{mL}$ and one $\mathrm{mL}$ of $2 \% \mathrm{AlCl}_{3}$ (dissolved in methanol) and the whole mixture was well stirred. After one hour of incubation at laboratory temperature and under shade, different absorbances were measured at $415 \mathrm{~nm}$ using a spectrophotometer (GENESYS 10S). For each analysis, mixtures were prepared in duplicate. For preparing the blank, the procedure was the same as described above but in lieu of the extract, one $\mathrm{mL}$ of methanol was added. The flavonoid content of the extracts was expressed in mg equivalent quercetin $(\mathrm{QE}) / \mathrm{g}$ of corresponding dry extract using the equation from the calibration line:

$$
\mathrm{y}=0.5001 \ln (\mathrm{x})+3.442 \text {, and } \mathrm{R}^{2}=0.944
$$

where $\mathrm{x}$ is the absorbance and $\mathrm{y}$ is the equivalent of quercetin $(\mathrm{mg} / \mathrm{g})$.

\subsubsection{Determination of anthocyanins}

The determination of the anthocyanin content of extracts was carried out by the procedure reported by Kapepula, [28] and Adepado et al., [29]. We sampled $0.5 \mathrm{~mL}$ of the $1 \mathrm{mg} / \mathrm{ml}$ solution of $1 \mathrm{mg} / \mathrm{ml}$ extract prepared in methanol $80 \%$, which was mixed with 3 $\mathrm{mL}$ of vanillin methanol solution $(4 \%)$ and $1.5 \mathrm{~mL}$ of hydrochloric acid. Then, the mixture was incubated for an hour and the absorbance was measured at $500 \mathrm{~nm}$. Mixtures are prepared in triplicate, and the average value was used. The same procedure was repeated for the reference substance (D-catechin) in the concentration range of $4 \mathrm{mg} / \mathrm{mL}$ to 0.125 
$\mathrm{mg} / \mathrm{mL}$ and allowed the calibration line to be established. The anthocyanin content of the extracts is expressed in $\mathrm{mg}$ equivalent $\mathrm{D}$-catechin per $\mathrm{g}$ of corresponding dry vegetable matter $(\mathrm{EC} / \mathrm{g})$ using the following equation from the calibration line:

$$
\mathrm{y}=0.0286 \mathrm{x}+0.0508 \text { and } \mathrm{R}^{2}=0.988
$$

where $\mathrm{x}$ is the absorbance and $\mathrm{y}$ is the catechin equivalent $(\mathrm{mg} / \mathrm{g})$.

\subsection{Evaluation of antioxidant activity}

The antioxidant activity was assessed according to Kapepula et al. [28].

\section{(i) Preparation of samples}

Ten $\mathrm{mg}$ of dry extract of each sample were dissolved in $1 \mathrm{~mL}$ of methanol for polar extracts and the mixture of dichloromethane-methanol (1:1) for apolar extracts (solution A: $10 \mathrm{mg} / \mathrm{mL}$ ). The dilution was carried out with different concentrations as follows: 8 $\mathrm{mg} / \mathrm{mL}, 6 \mathrm{mg} / \mathrm{mL}, 4 \mathrm{mg} / \mathrm{mL}$ and $2 \mathrm{mg} / \mathrm{mL}$.

\section{(i) ABTS Radical Scavenging Capacity}

In reaction with potassium or sodium persulfate $\left(\mathrm{K}_{2} \mathrm{~S}_{2} \mathrm{O}_{8}\right)$, the ABTS $\left(2,2^{\prime}\right.$-azino-bis3-ethylbenz-thiazoline-6-sulfonic acid) forms the cationic radical ABTS from blue to green color. The addition of antioxidant reduces this radical and causes the mixture decolorization. The decolorization of the radical measured by spectrophotometry at $734 \mathrm{~nm}$ is proportional to the concentration of antioxidants.

Dissolve in $500 \mu \mathrm{L}$ of distilled water a quantity of ABTS reagent corresponding to 20 millimoles: solution A. Then dissolve in $500 \mu \mathrm{L}$ of distilled water a quantity of potassium persulphate $\left(\mathrm{K}_{2} \mathrm{~S}_{2} \mathrm{O}_{8}\right)$ corresponding to 10 millimoles: solution B. Therefore, mix both solutions $\mathrm{A}$ and $\mathrm{B}$ at equal volume and keep the mixture away from light between 12 and 16 hours: this solution constitutes the stock solution for ABTS radical. Then dilute the stock solution of the radical with methanol $x$ times in order to obtain an analytical solution of which the absorbance ranges between 0.800 and 1.000. In a test tube, place $20 \mu \mathrm{L}$ of methanol with $1980 \mu \mathrm{L}$ of solution of ABTS: control solution. On the other hand, in another test tube, place $20 \mu \mathrm{L}$ of the sample solution for each concentration level, and add to this solution $1980 \mu \mathrm{L}$ of ABTS radical working solution and incubate for 30 minutes in the absence of light. Successive reading of solutions for each concentration level is performed at $734 \mathrm{~nm}$ with the spectrophotometer: blank (methanol), control solution and samples.

The percentage inhibition of ABTS radical is determined as follows:

$$
\% \text { inhibition }=\left[1-\frac{A_{x}}{A_{c}}\right] x 100
$$

Where,

Ax: the absorbance of ABTS radical in the presence of the extract

Ac: absorbance of ABTS (control solution)

The ABTS scavenging activity of extracts was expressed in IC 50 . Different IC 50 values were determined using Graph Pad Prism version 6.0 software. The experiment was performed in triplicate.

\section{(ii). DPPH Radical Scavenging Capacity}

This method is based on the degradation of DPPH radical (2,2 DiPhenyl-1-PicrylHydrazyl). The DPPH radical is a violet-colored radical, the addition of antioxidant reduces this radical and causes the mixture to discolor. This radical decolorization measured by spectrophotometer at $517 \mathrm{~nm}$ is proportional to the concentration of antioxidants 
Dissolve $3.2 \mathrm{mg}$ of DPPH in $100 \mathrm{~mL}$ of methanol (80\%) and this solution is kept out in the dark for at least an hour. The absorbance of this solution must be adjusted to $0.7 \pm 0.05$ using methanol (80\%). So, in a test tube, mix $20 \mu \mathrm{L}$ of methanol with $1980 \mu \mathrm{L}$ of DPPH radical solution: control solution. In another test tube, place $20 \mu \mathrm{L}$ of sample for each concentration by adding to $1980 \mu \mathrm{L}$ solution of DPPH radical working solution and incubate for 30 minutes in the absence of light. Successive reading of the solutions for each concentration is carried out using a spectrophotometer at $517 \mathrm{~nm}$ : blank (methanol), control solution and different sample solutions. The DPPH radical inhibition percentage for each sample was determined using the following formula:

$$
\% \text { inhibition }=\left[1-\frac{A x}{A c}\right] x 100
$$

Where,

Ax: the absorbance of DPPH radical in the presence of the extract

Ac: absorbance of DPPH (control solution)

DPPH scavenging activity of extracts was expressed in $\mathrm{IC}_{50}$. Different $\mathrm{IC}_{50}$ values were determined using Graph Pad Prism version 6.0 software. Each sample was measured in triplicate.

\subsubsection{Evaluation of antibacterial activity}

The antibacterial activity was evaluated by the micro-dilution method using the liquid medium as previously reported [25]. The test extract $(20 \mathrm{mg})$ was first dissolved in 250 $\mu \mathrm{L}$ of DMSO and the final volume was adjusted to $5 \mathrm{~mL}$ within Mueller Hinton culture medium (final DMSO concentration of 5\%). The bacterial suspension was prepared by placing three isolated colonies of the test strains (Staphylococcus aureus ATCC 25923, Escherichia coli ATCC 8739 and Pseudomonas aeruginosa ATCC9027) in $2 \mathrm{~mL}$ physiological water for each strain and incubating for 24 hours to obtain $0.5 \mathrm{McFarland}\left(10^{8} \mathrm{cells} / \mathrm{mL}\right)$ at $37^{\circ} \mathrm{C}$. The bacterial suspension is then diluted to $10^{6} \mathrm{cell} / \mathrm{s} / \mathrm{mL}$ ( $1 / 100$ dilution). Various bacterial suspensions are cultured in Petri dishes containing Mueller Hinton medium using the swabbing technique. Using a pasteur pipette, wells are dug in Mueller Hinton agar poured into the petri dish. Then, $100 \mu \mathrm{L}$ of the different concentrations of each extract are distributed in each well. The positive control was placed in another well. After diffusion, the cultures are incubated in the oven at $37^{\circ} \mathrm{C}$ for 24 hours, and the inhibition rings are measured around each well.

\section{Result and discussion}

\subsection{Organoleptic tests}

It was observed that Cola acuminata has following organoleptics characteristics : its powder is fine, its color was yellow, its odor was strong and its taste was bitter.

\subsection{Histological characteristics}

The micrography performed on the nut powder of $C$. acuminata is presented in Figure 2 below. 

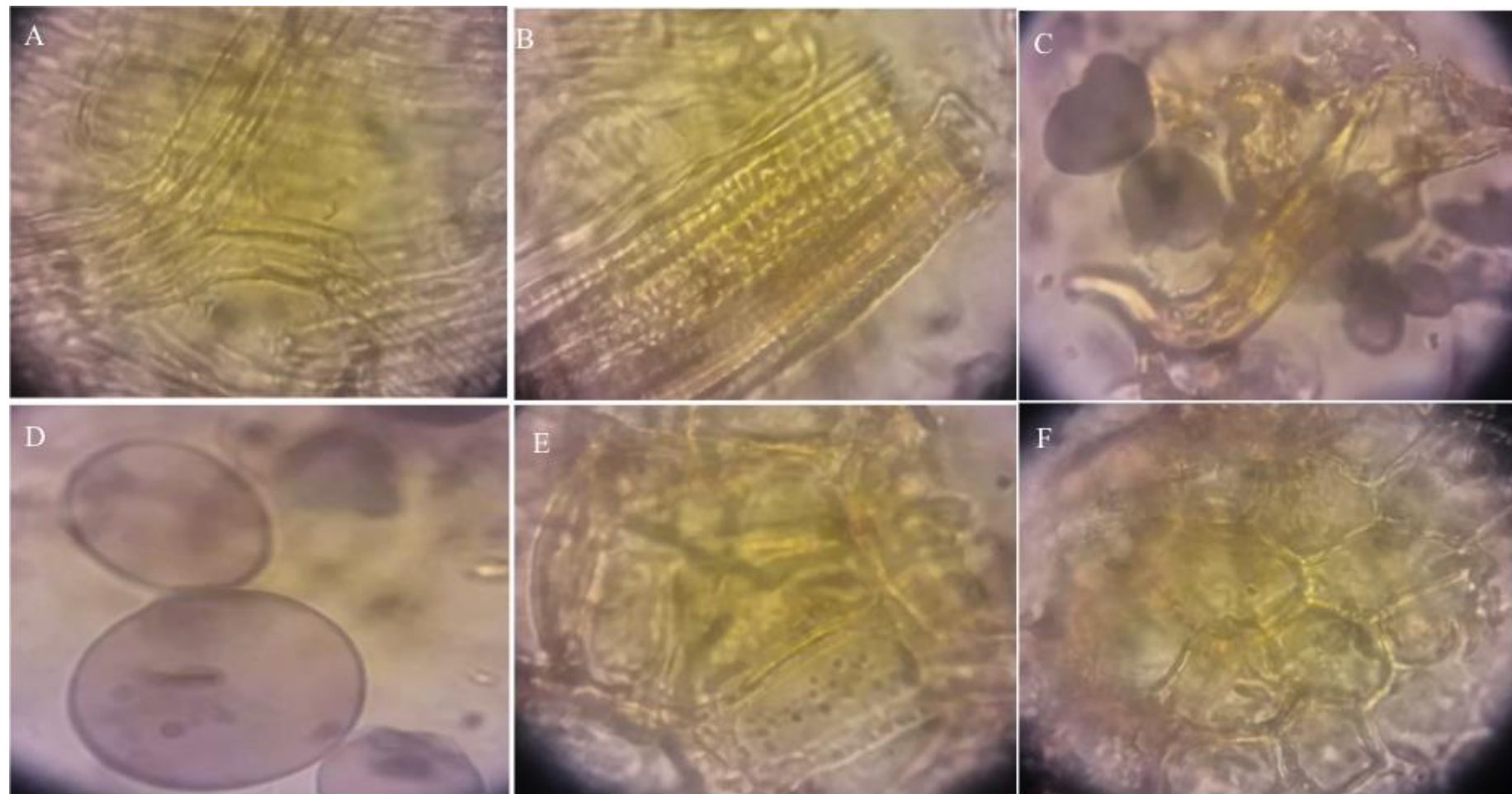

Figure 2. Microscopic characteristics of C. acuminata : fragments of fibers (A), spiral vessels (B), trichomes (smooth unicellular hairs) (C), ovoid starch grains (D), fragments of sclerenchyma (E), fragment of the endosperm $(\mathrm{F})$

The micrography analysis of $C$. acuminata revealed the presence of following histological elements, namely: the fibers, the spiral vessels, the trichomes, the ovoid starch grains, the sclerenchyma and the fragments of the endosperm.

To the best of our knowledge, no information has been reported before on the micrographic study of this species. Given their use in traditional medicine, it is important to enhance the value of these plants while standardizing, from which the determination of the histological elements of drugs for the preparation of monographs is essential for the detection of falsifications.

\subsection{Yield of extraction}

After a threefold maceration of 48 hours, the extraction yield of the drug is presented as follows: Methanol (16\%), Water (4\%), Dichloromethane (1.5\%), Ethyl acetate $(0.5 \%)$ and n-hexane $(0.37 \%)$. As observed, the best yield was obtained with the methanol fraction (apolar solvent); followed by the aqueous, dichloromethane, acetate and n-hexane fractions.

The method used to obtain dichloromethane fractions is suitable for the extraction of terpenic acids such as oleic, betulinic and maslinic acids. For methanol (apolar solvent) and aqueous (polar solvent) fractions, C. acuminata presented a good yield. This shows that the metabolites quantitatively important in the seeds of this species are those that pass easily through polar and non-polar solvents, of which polyphenols including anthocyanins, tannins, flavonoids, cardiac glycosides, volatile oils but also alkaloids. These findings are similar to those reported by Efe et al. [30].

\subsection{Secondary metabolites}

\subsubsection{Anthocyanins}



below.

The TLC analysis performed for the search of anthocyanins is presented in the figure

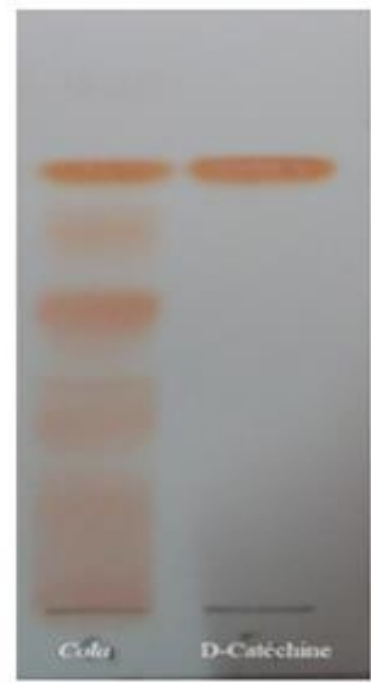

Figure 3. TLC chromatogram from methanol extract of $C$. acuminata in the visible for the search of anthocyanins

It was observed the appearance of a red coloration that turned purplish-greenish blue. The chromatogram analysis provides the information on the presence of anthocyanins in Cola nuts, including D-Catechin. These findings are similar to those found by Ghedira [31]. The presence of anthocyanins gives the plant properties such as capillary resistance, allows the treatment of venous insufficiency of certain ophthalmic disorders. A new action of anthocyanins in potentiating certain drugs against gastroesophageal reflux disease has been reported by Pierrot et al., [32].

\subsubsection{Terpenoids and Iridoids}

The analysis of Figures 4 and 5 below shows that various colours observed in the chromatographic profile of the dichloromethane extract (violet, orange colour) indicate the presence of terpenes (Figure 4) and iridoids (Figure 5) respectively. 


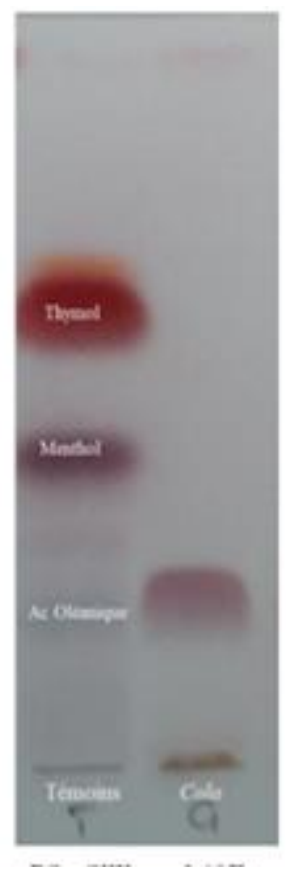

Figure 4. TLC chromatogram from dichloromethane extract for terpenoids in C. acuminata in the visible

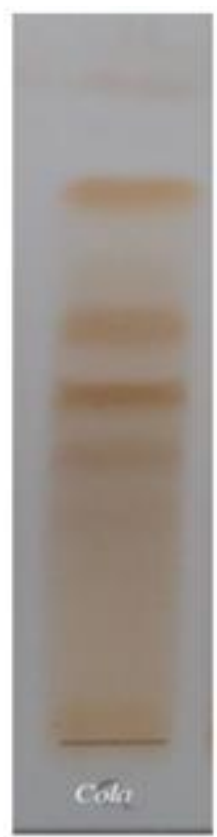

Figure 5. TLC chromatogram from dichloromethane extract of $C$. acuminata for the search of iridoids in the visible

These results are similar to those obtained previously by Dewole [33]. In Figure 4, true iridoids are indicated in the plant by spots of different colours and black spots correspond to terpenes of which monoterpenes are responsible for the smell of essential oils. The presence of these compounds in a plant species could give it biological properties, including anti-rheumatic, hypotensive, sedative actions of the central nervous system (CNS) and antioxidant action [18]. 


\subsubsection{Tannins}

The figure below shows the presence of tannins in C. acuminata.

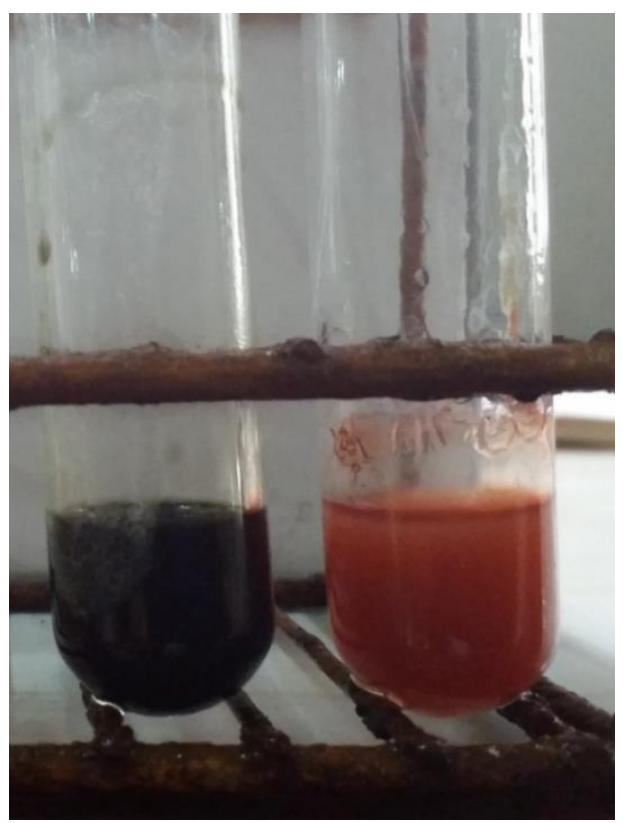

Figure 6. Blaskish-blue precipitate and pink of C. acuminata in Ferric chlorine and Stiasny reagent.

In Figure 6, the presence of tannins is indicated in the plant by the greenish-black colouring for gallic tannins and the pink colouring for catechic tannins. The presence of these compounds in a plant species could give it biological properties, including antiviral and anti-inflammatory properties. These results are similar to the study conducted by Dewole et al. [33].

It should be noted that with the exception of compounds in which chromatograms are shown above, other compounds have also been detected. These include in particular the cardiotonic heteroglycosides reported in the plant, as confirmed by certain studies, in particular that of Kunoma [34]. These compounds are limiting factors plants to be used as food. However, these compounds are used in medicine and also in the manufacture of steroidal drugs; they are used to treat heart failure. These drugs can have both negative and positive effects on the kidneys, heart, stomach and the central nervous system [18]. The alkaloid test gave a negative response to the Draggendorff reagent, and by comparing these results of the alkaloid test with previous work, we note that the absence of these compounds in C. acuminata has not been reported. In addition, this absence can be justified by the difference in soil and/or climatic conditions.

\subsubsection{Content in Secondary metabolites}

The results of the assays of secondary metabolites of which phenolic compounds are reported in the table below.

Table 1. Content in phenolic compounds of C. acuminata

\begin{tabular}{cccc}
\hline Sample & $\begin{array}{c}\text { Total polyphenol con- } \\
\text { tent (EAG) }\end{array}$ & $\begin{array}{c}\text { Flavonoid con- } \\
\text { tent (EQ) }\end{array}$ & $\begin{array}{c}\text { Anthocyanin con- } \\
\text { tent (EC) }\end{array}$ \\
C. acuminata & $38.69 \pm 2.12$ & nd & $1.44 \pm 0.006$ \\
\hline
\end{tabular}

Legend: GAE/g Equivalent of gallic acid (GAE) per g of dried extract; QE/g Equivalent of quercetin $(\mathrm{QE})$ per $\mathrm{g}$ of dried extract. nd: non determined due to the absence of flavonoids. 
These findings showed that $C$. acuminata is rich in total polyphenols other than flavonoids and phenolic acids. These results corroborate with the phytochemical screening that showed the absence of flavonoids. C. acuminata is reported to be rich in tannins, anthocyanins and other compounds, the nature of which remains to be determined.

\subsection{Evaluation of the antioxidant activity}

The evaluation of anti-scavenging activity is presented in the table below. The results of the antioxidant activity of the various extracts by in vitro chemical tests with ABTS and DPPH were expressed in terms of the inhibitory concentration 50 (IC50).

Table 2. IC50 values $(\mu \mathrm{g} / \mathrm{mL})$ of extracts for ABTS and DPPH tests

\begin{tabular}{ccc}
\hline Samples & ABTS $(\mu \mathrm{g} / \mathrm{mL})$ & DPPH $(\mu \mathrm{g} / \mathrm{mL})$ \\
\hline Dichloromethane fractions & - & $82.79 \pm 8.62$ \\
Ethyle Acetate fraction & $4.02 \pm 0.57$ & $40.18 \pm 5.74$ \\
Methanol fraction & $5.62 \pm 0.55$ & $24.89 \pm 1.53$ \\
Aqueous fraction & $6.74 \pm 0.4$ & $28.58 \pm 3.04$ \\
Gallic acid & $0.71 \pm 0.08$ & $1.07 \pm 0.10$ \\
\hline
\end{tabular}

All fractions showed IC 50 values lower than $10 \mu \mathrm{g} / \mathrm{mL}$ in the ABTS test and lower than $100 \mu \mathrm{g} / \mathrm{mL}$ in the DPPH test. All extracts displayed the ability to inhibit radicals that vary significantly in each type of test. This difference in activity would be explained by the different chemical composition (qualitative and quantitative) of each fraction in terms of secondary metabolites. In addition, it can be noted that the inhibitory concentration 50 (IC50) values obtained in the ATBS test are lower than those of the DPPH test. This difference in activity is attributed to the mechanisms of the reactions. Indeed, ABTS reacts at the same time with hydrophilic and lipophilic compounds while DPPH reacts only with hydrophilic compounds [35].

The anti-scavenging activity is an indicator of the antioxidant activity, and in view of these results $C$. acuminata has interesting antioxidant properties attributed to the presence of phenolic compounds of which anthocyanins, tannins [36-38]. Polyphenols are the most common secondary metabolites in the plant kingdom. They have several biological properties including the antioxidant capacities for which they are indicated in the management of various diseases, and based on the Student test, there is no significant difference between methanol and aqueous fractions.

\subsection{Evaluation of the antibacterial activity}

The table below presents the antibacterial activity of $C$. acuminata extracts on three bacterial strains. These findings are in agreement with the phytochemical screening results, which showed that it is the two extracts that gave the best extraction yield.

Table 3. Anti-bacterial activity of C. acuminata on Mueller-Hinton (mm)

\begin{tabular}{ccccccc}
\hline \multicolumn{2}{c}{ Methanol } & \multicolumn{5}{c}{ Water } \\
\hline Concentration $(\mu \mathrm{g} / \mathrm{mL})$ & Sa & Pa & Ec & Sa & Pa & Ec \\
\hline 2000 & + & + & - & - & - & - \\
1000 & + & + & + & + & + & + \\
500 & + & + & + & + & + & + \\
250 & + & + & + & + & + & + \\
125 & + & + & + & + & + & + \\
\hline
\end{tabular}

Legend: Sa: Staphylococcus aureus, Pa: Pseudomonas aeruginosa, Ec: Escherichia coli 
From the above table, it was observed that all three strains were sensitive to methanolic and aqueous extracts. The antibacterial power is more or less important depending on the nature of the strain and the culture medium used. Studies have shown that the types of solvents used have an effect on the nature of the extracted compounds and the bioactivity of the resulting extract. This clearly implies that the polarity of solvents (more polar and less polar) plays an essential role in the extraction of bioactive compounds, which influences the antimicrobial activity.

The aqueous and methanol extracts of $C$. acuminata gave a good inhibition zone against the selected tested microorganisms (E. coli, S. aureus, P. aeruginosa). The extracts of C. acuminata were very potent in terms of activity due to the relative presence of bioactive components. Previous work has shown that the presence of secondary metabolites such as alkaloids, anthocyanins, anthraquinones, flavonoids, polyphenols, saponins, tannins, steroids and triterpenes in plants would confer anti-bacterial activity [39-40]. The broad spectrum of activity presented by $C$. acuminata against gram positive and gram negative bacteria probably explains their use in a wide range of diseases in developing countries. Several antimicrobial-resistant bacteria are problematic and complicate the treatment of bacterial infections. These results corroborate with the work of Efe [30].

\section{Conclusion}

Medicinal plants are still the first reservoir of new drugs. They are considered as a source of essential raw materials for the discovery of new molecules needed for the development of future drugs. To this end, secondary metabolites are the subject of much research, this is particularly the case of plant polyphenols which are widely used in therapy as vasculo-protectors, anti-inflammatory, enzymatic inhibitors or antioxidants. In order to enhance the value of medicinal plants. The results obtained show that a large part of the constituents of the crude extract remain in the aqueous and methanol fraction with yields of $4 \%$ and $16 \%$, respectively.

The IC50 values of the various extracts of our species testify to their anti-scavenging activity towards the radicals used. The IC 50 values of the ABTS test are lower than those of the DPPH test. All the tested strains were sensitive to the extracts of $C$. acuminata using different solvents.

Finally, the present study showed the richness of the plant studied in phenolic and terpenoid compounds, which explains its antioxidant and anti-bacterial properties; and shows the importance of its use in local medicine as antimicrobial agents. It could therefore be a less expensive alternative for the treatment of different diseases.

These results are still preliminary, it would therefore be interesting to continue the investigations on this plant of interest, it would therefore be important to support these results by focusing on:

- Purification and identification of active ingredients,

- The study of their toxicity on different cell lines (in vitro) and on models using animals (in vivo) in order to determine therapeutic doses and lethal doses because traditional remedies suffer a lot from the dosage problem,

- Test the antidiabetic and anti-inflammatory activity of $C$. acuminata; these biological activities respond to the major uses of the plant according to the results of the ethnobotanical survey.

- This study is partly about the traditional use of plants, but today, with the rapid degradation of the environment followed by the disappearance of many plant species, pharmacognosy studies must no longer be limited to species that are the subject of 
traditional use, but to all available species at the risk of bringing out molecules that will remain forever known.

\section{Conflict of interest}

The authors declare no conflict of interest to disclose.

\section{References}

[1] Pathy, K.K., Flavien, N.B., Honoré, B.K. et al. Ethnobotanical characterization of medicinal plants used in Kisantu and MbanzaNgungu territories, Kongo-Central Province in DR Congo. J Ethnobiology Ethnomedicine 17, 5 (2021). https://doi.org/10.1186/s13002-020-00428-7

[2] Hong-Fang J, Xue-Juan L and Hong-Yu Z (2009). Natural products and drug discovery. Can thousands of years of ancient medical knowledge lead us to new and powerful drug combinations in the fight against cancer and dementia? EMBO Reports, 10(3):194-200

[3] Fokunang CN, Ndikum V, Tabi OY, Jiofack RB, Ngameni B, Guedje NM, Tembe-Fokunang EA, Tomkins P, Barkwan S, Kechia F, Asongalem E, Ngoupayou J, Torimiro NJ, Gonsu KH, Sielinou V, Ngadjui BT, Angwator F, Nkongmeneck A, Abena OM, Ngogang J, Asonganyi T, Colizzi V, Lohoue J and Kamsu-kom (2011). Traditional medicine: Past, present and future research and development prospects and integration in the National health system of Cameroon. African Journal of Traditional, Complementary and Alternative Medicines, 8(3):284-295.

[4] Kouadio BCD, Fofie NBY, Kanga Y, Basile YA, Yapo YC, Ambe SA et Zirihi GN (2016). Étude ethnobotanique des plantes médicinales utilisées dans le Département de Transua, District du Zanzan (Côte d'Ivoire). Journal of Animal \&Plant Sciences, 27(2) : 4230-4250

[5] Ekor M (2013). The growing use of herbal medicines: issues relating to adverse reactions and challenges in monitoring safety. Frontiers in Pharmacology, 4:177

[6] Yuan H, Ma Q, Ye L and Piao G (2016). The traditional medicine and modern medicine from natural products. Molecules, 21(5):559-

[7] Abullahi AA (2011). Trends and Challenges of Traditional medicine in Africa. African Journal of Traditional, Complementary and Alternative medicines, 8(5):115-123

[8] Sofowora A, Ogunbodede E and Onayade A (2013). The role and place of medicinal plants in the strategies for disease prevention. African Journal of Traditional, Complementary and Alternative medicines, 10(5):210-229

[9] Anand U, Jacobo-Herrera N, Altemimi and Lakhssassi N (2019). A comprehensive review on medicinal plants as antimicrobial therapeutics: potential avenues of biocompatible drug discovery. Metabolites, 9(11):258-271

[10] Newman DJ and Cragg GM (2020). Natural products as sources of new drugs over the nearly four decades from 01/1981 to 09/2019. Journal of Natural Products, 83(3):770-803

[11] Howes MJR, Quave CL, Collemare J, Tatsis EC, Twilley D, Lulekal E, Farlow A, Li L, Cazar ME, Leaman DJ, Prescott TAK, Milliken W, Martin C, De Canha MN, Lall N, Qin H, Walker BE, Vasquez-Londono C, Allkin B, Rivers M, Simmonds MSJ, Bell E, Battison A, Felix J, Forest F, Leon C, Williams C and Lughadha EN (2020). Molecules from nature: reconciling biodiversity conservation and global healthcare imperatives for sustainable use of medicinal plants and fungi. Plants, People, Planet, 2(5):463-481.

[12] Dias DA, Urban S and Roessner U (2012). A historical overview of natural products in drug discovery. Metabolites, 2(2):303306

[13] Yuan H, Ma Q, Ye L and Piao G (2016). The traditional medicine and modern medicine from natural products. Molecules, 21:559-577

[14] Lautié E, Russo O, Ducrot P and Boutin JA (2020). Unraveling plant natural chemical diversity for drug discovery purposes. Frontiers in Pharmacology, 11:397-434

[15] Efferth T, Alexie G, Andersch K and Banerjee M (2020). First nations healing: from traditional medicine to experimental ethnopharmacology. Zeitschrift für Anglistik und Amerikanistik, 68(2):159-175. https://doi.org/10.1515/zaa-2020-0017

[16] Atanasov AG, Waltenberger B, Pferschy-Wenzig EM, Linder T, Wawrosch C, Uhrin P, Temml V, Wang L, Schwaiger S, Heiss EH, Rollinger JM, Schuster D, Breuss JM, Bochkov V, Mihovilovic MD, Kopp B, Bauer R, Dirsch and Stuppner H (2016). Discovery and resupply of pharmacologically active plant-derived natural products: a review. Biotechnology Advances, 33(8):15821614

[17] Berhanu AM. and Kinfe HH (2018). "Secondary metabolites, their structural diversity, bioactivity, and ecological functions: An overview" Physical Sciences Reviews, vol. 4, no. 6, 2019, pp. 20180100. https://doi.org/10.1515/psr-2018-0100

[18] Panche AN, Diwan AD and Chandra SR (2016). Flavonoids: an overview. Journal of Nutritional Science, 5:e47

[19] Dhalaria R, Verma R, Kumar D, Puri S, Tapwal A, Kumar V, Nepovimova E and Kuca K (2020). Bioactive compounds of edible fruits with their anti-aging properties: A comprehensive review to prolong human life. Antioxidants, 9:1123-1161

[20] Dias MC, Pinto DCGA and Silva AMS (2021). Plant flavonoids: Chemical characteristics and biological activity. Molecules, 26:5377-5393 
[21] Tungmunnithum D, Thongboonyou, Pholboon A and Yangsabai A (2018). Flavonoids and other phenolic compounds from medicinal plants for pharmaceutical and medical aspects: an overview. Medicines, 5(3):93-109

[22] Iqbal J, Abbasi BA, Mahmood T, Kanwal S, Ali B, Shah SA and Khalil AT (2017). Plant-derived anticancer agents: a green anticancer approach. Asian Pacific Journal of Tropical Biomedicine, 7(12):1129-1150

[23] Djahra AB (2016). Etude phytochimique, antimicrobienne, antioxydante et anti hépatotoxique du Marrube blanc ou Marubium vulgare L. Thèse de doctorat en sciences Biologiques, université Badji Mokhtar-Annaba/Algerie, 114pp.

[24] Kuete V and Efferth T (2010). Cameroonian Medicinal Plants: Pharmacology and derived natural products. Frontiers in Pharmacology, 1:123

[25] Bongo G, Inkoto C, Masengo C, Tshiama C, Lengbiye E, Djolu R, Kapepula M, Ngombe K, Mbemba T, Tshilanda D, Mpiana P, Ngbolua KN (2017). Antisickling, Antioxidant and Antibacterial Activities of Afromomum alboviolaceum (Ridley) K. Schum, Annona senegalensis Pers. and Mondia whitei (Hook. f.) Skeels. American Journal of Laboratory Medicine, 2(4): 52-59

[26] Uwabunkeonye OC, Ezeabara CA, Horoiheoma C, Denis UC, Aziagba BO (2015). Comparative phytochemical and proximate compositions of Cola acuminata (P.Beauv.) Schott and Cola nitida (vent.) Schott and Endl. Journal of Ethnopharmacognosy 3(3):26-29.

[27] Loukmane B (2015). Contribution à l'étude phytochimique et évaluation de l'activité Antioxydante de la plante médicinale Crataegus monogyna. Université des Frères Mentouri Constantine Faculté des Sciences de la Nature et de la Vie.

[28] Kapepula PM, Mbombo PM, Franck F, Mouithys-Mickalad A, Mumba ND, Di- bungi KP, Kabamba NN, Tits M, Frédérich M, Tamfum MJJ. (2017). Antioxidant potentiality of three herbal teas consumed in Bandundu rural areas of Congo. Natural Product Research;31(16):1-4.

[29] Adedapo AA, Jimoh FO, Koduru S , Afolayan AJ, Masika PJ. (2008). Antibacterial and antioxidant properties of the methanol extracts of the leaves and stems of Calpurnia aurea. BMC Complementary and Alternative Medecine.8 :1-8.

[30] Efe MO, Asefon OA, Stephen AJ (2016). The phytochemical constituents and relative antimicrobial activities against clinical pathogens of different seed extract of Cola nitida (vent.), Cola acuminata (Beauvoir) and Cola garcinia (Heckel) grown in southwest, Nigeria . Journal of Pharmacognosy and Phytochemistry, 6(1) :493-501.

[31] Ghedira Kamel, Maria LuciaLeporti (2009). Comparative analysis of medical plants used in traditionnal medecinal in Italy and Tunisia. Journal of ethnobiology and ethnomeddecine ; https://doi.org/10.1186 /1746-4269-5-31

[32] Pierrot FD. et Coll. (2013) Rôles des anthocyanes. Société d'horticulture.

[33] Dewole E. A., D.F.A. Dewuni, JYT Alabi and A. Adegoke (2013). Proximate and screening phytochemical of Cola nitida and Cola acuminata.P akistan journal of biological sciences, 16 (22):1593-1596

[34] Kunoma A. I., Muhammed I, Ibrahim ID., Shehu K, Maishanu HM, Isahet AD (2014). Phytochemical of various species of cola nut extracts for antifungal activity against phytopathogenical fungi. American Journal of Biology and Life Sciences. 2014; $2(1): 18-23$

[35] Flogel A, Kim DO, Chung SJ, Koo SI, Chun OK. (2011). Comparison of ABTS/DPPH assays to measure antioxidant capacity in popular antioxidant-rich US foods. Journal of Food Composition and Analysis ; 24(7):1043-8.

[36] Imene R. (2013). Etude In vitro de l'activité anti-Leishmanienne de certaines plantes médicinales locales : cas de la famille deslamiacées. Thèse en vue d'obtention du diplôme : Magister en Biologie Appliquée. Université CONSTANTINE 1/ ALGERIE.

[37] El Gharras H. (2009). Polyphenols: Food sources, properties and applications - A review. International Journal of Food Science and Technology, 44(12), 2512-2518.

[38] Perron N. R. \& Brumaghim J. L. (2009). A review of the antioxidant mechanisms of polyphenol compounds related to iron binding. Cell Biochemistry and Biophysics, 53(2), 75-100.

[39] Kuete V, Ngameni B, Simo CCF, Tankeu RK, Ngadjui BT, Meyer JJM, Lall N, Kuiate JR. (2008). Antimicrobial activity of the crude extracts and compounds from Ficus chlamydocarpa and Ficus cordata (Moraceae). J Ethnopharmacol, 120:17-24.

[40] Kuete V. (2010). Potential of Cameroonian plants and derived products against microbial infections: A review. Planta Med, 76(14):1479-1491. 